\title{
Climate change in the context of whole-farming systems: opportunities for improved outreach
}

\author{
R. S. Clements ${ }^{1,2}$ (D) S. K. Birthisel ${ }^{1,3} \cdot$ A. Daigneault ${ }^{3} \cdot$ E. Gallandt ${ }^{2} \cdot$ D. Johnson ${ }^{4}$. \\ T. Wentworth ${ }^{4} \cdot$ M. T. Niles ${ }^{4}$
}

Received: 7 August 2020 / Accepted: 19 April 2021 / Published online: 9 June 2021

(C) The Author(s) 2021

\begin{abstract}
Climate change poses a challenge to farming systems worldwide. However, existing research suggests that farmers and those providing outreach may have different climate change perspectives, and there is little understanding of how farmers prioritize climate change compared with other aspects of their farming system. To compare how farmers and outreach professionals in northern New England consider climate change within the context of whole-farming systems, we conducted mental modeling interviews with 33 farmers and 16 outreach professionals. Despite being primed to consider climate during the interviews, only $24 \%$ of farmers and $25 \%$ of outreach professionals included climate in their mental models. Key differences arose in both group's perceptions of weather: outreach professionals focused on connections between good weather and biophysical factors, while farmers drew additional connections to factors like quality of life and overall farm success. Social factors including community well-being, public education, and farm success were significantly more likely to be included $(P<0.05)$, and in some cases were more influential, in farmer models compared to outreach professional models. We conclude that farmer participants did not perceive climate to be a central factor of their farming systems, and valued human and social dimensions more highly than outreach professionals perceived. These factors may warrant special consideration in efforts to make outreach meaningful to local contexts, along with framing climate change within its broader relationship to other farming system aspects. Interdisciplinary teams may be helpful in developing outreach approaches that fully contextualize climate change within farmers' complex whole-farm management perspectives.
\end{abstract}

Keywords Climate change $\cdot$ Mental models $\cdot$ Farmers · Outreach professionals · Community · Quality of life

R. S. Clements

ruth.sexton@maine.edu

Extended author information available on the last page of the article 


\section{Introduction}

Climate change poses a pressing threat to food security and rural livelihoods worldwide, but climate impacts and needed responses can be highly region-specific (IPCC 2019). In the New England region of the United States of America (USA), climate change is already impacting farming, with increasing rates of precipitation variability and extreme weather events over the last century (Fernandez et al. 2020; Wolfe et al. 2018). The region is expected to warm more quickly than most other regions in the USA by 2050 (Karmalkar and Bradley 2017). Many regional farmers are concerned about these changes: almost $50 \%$ of surveyed farmers in Vermont believed that climate change would negatively impact their farm (Schattman et al. 2018). However, less than 50\% of New England farmer respondents reported confidence that they had the technical, financial, and social capacity to deal with weather-related risks on their farm (White et al. 2018).

Farmers' perceived capacity to manage risks on their own farms influences how and whether they implement strategies to adapt to climate change (Niles et al. 2016). Outreach approaches that center the role of farmers as co-producers of solutions with outreach professionals, to ensure agricultural resources are adaptable to local contexts and to help build farmers' capacity for addressing risk, are increasingly being called upon (Brown et al. 2018; Demenois et al. 2020; Kingiri 2020). However, differences in how outreach professionals and farmers conceptualize climate change and its impact on farming systems could affect outreach and co-production outcomes.

Considerable research has been done to understand how farmers perceive and respond to climate change (Chatrchyan et al. 2017; Haden et al. 2012; Findlater et al. 2018a; Findlater et al. 2018b; Jemison et al. 2014; Niles et al. 2016; White et al. 2018). Farmers in our region are more likely to believe in climate change than those in some other US regions: $80 \%$ of farmers surveyed in Vermont believed in climate change (Schattman et al. 2018), compared with 54\% of farmers in California and 66\% of those in the Midwest (Prokopy et al. 2015).

However, despite the fact that the majority of farmers believe in climate change and acknowledge its increasing challenges (Chatrchyan et al. 2017), there is little understanding about how farmers place climate change within their broader farming system as a priority. Yet, there are two main reasons to suspect that climate change may not be central to a farmer's perception of their farming system. First, there is evidence to demonstrate that US farmers have less climate change belief than the general public (e.g., Gareau et al. 2018; Prokopy et al. 2015). Second, while public opinion polls generally show the majority of the US public believe in climate change and seek action for dealing with its challenges (e.g., Resources for the Future 2020), polls also show that climate change usually ranks as a lower priority among the public compared with other potential issues. For example, in the 2019 Pew Research poll on US public priorities, climate change ranked 17 out of 18 issues in terms of priority. This suggests that while people are increasingly concerned about climate change, it continues to be of lesser priority than other perceived economic or health issues. We expect then that farmers, with potentially lower climate change belief and concern than the general public, and with the general public seeing other issues as priorities, will not place climate change as a central issue to their farming systems.

Furthermore, studies comparing how farmers and outreach professionals perceive climate change indicate that these groups may or may not see eye-to-eye (Chatrchyan et al. 2017; Eitzinger et al. 2018; Hansen et al. 2004). A survey in the Midwest showed that less than half as many farmers believed climate change was occurring and due mostly to human activities as 
compared with outreach professionals (Prokopy et al. 2015). However, in regard to the financial, social, and ecological attributes of specific climate adaptation practices, farmers and outreach professionals in Vermont shared similar perceptions (Schattman et al. 2018). Personal experience with extreme weather events may influence farmers' and outreach professionals' perceptions of climate change, (Chatrchyan et al. 2017; Haden et al. 2012; Niles et al. 2019), though not all studies agree (van der Linden 2014; Maas et al. 2020; Marlon et al. 2019). The diverse perspectives on climate change held by farmers and outreach professionals may thus be influenced by a number of factors, including individual attitudes and objectives (Austin et al. 1998; Edwards-Jones 2006; Haden et al. 2012; Halbrendt et al. 2014; Willock et al. 1999), education, and personal experiences (Eitzinger et al. 2018; Haigh et al. 2015).

A strong understanding of local stakeholder groups and contexts provides a foundation for knowledge co-production, research, and outreach approaches that are tailored to local contexts (Meadow et al. 2015). In Maine and Vermont, over $90 \%$ of farmers are considered small- and medium-scale by the United States Department of Agriculture (NASS 2017). At least $30 \%$ of these producers have farmed for 10 years or less (NASS 2017). Beginning farmers are historically underserved in terms of federal resources and often face greater financial obstacles than well-established farmers (Ahearn 2011; Ahearn and Newton 2009; GAO 2007). Given this context, we chose to target small to medium-scale and beginning farmers in northern New England in the present study. Our purpose was to identify how these stakeholders and outreach professionals with whom they interact perceive farming systems, how climate change plays a role in these perceptions, and how this information may inform tailored outreach and communication efforts on climate resilience.

Our specific research questions and hypotheses were:

1) How does climate change fit within the whole-farm management perspectives of small to medium-scale and beginning farmers and outreach professionals in our region?

H1: Farmers will not place climate change as a central aspect of their mental model.

2) Are there key differences that exist between farmer and outreach professional conceptions of climate change and/or farming systems?

$\mathrm{H} 2$ : Farmers and outreach professionals will have different perspectives of climate change and farming systems, reflected in their mental models.

3) What opportunities exist to improve outreach and communication on climate resilience for farmers in our region?

To address these questions, we compared mental models (Craik 1943; Özesmi and Özesmi 2004) — the ways in which people think about a system and its structure — of farming systems from outreach professionals and small to medium-scale and beginning farmers in Maine and Vermont.

\section{Methods}

To understand how climate change fits within farmer and outreach professional understanding of whole-farming systems (research question 1) and explore differences in perspectives between these groups (research question 2), we conducted mental modeling interviews with farmers and outreach professionals in Northern New England, USA. Mental models were first 
conceptualized by Craik (1943) and offer an established framework for understanding stakeholder perceptions and decision-making in complex social-ecological systems (Gray et al. 2012; Halbrendt et al. 2014; Jones et al. 2011; Kosko 1986; Olazabal et al. 2018; Özesmi and Özesmi 2004), including farming systems (Findlater et al. 2018a; Findlater et al. 2018b; Halbrendt et al. 2014; Jabbour et al. 2014; Schoell and Binder 2009a; Schoell and Binder 2009b). Through elicitive interviews, facilitators guide participants in identifying concepts in a system and causal relationships between them (Kosko 1986), which can be represented both mathematically and through intuitive visual models (Özesmi and Özesmi 2004; see Fig. 1 for an example).

Recent calls in the literature for greater transparency in reporting participatory modeling methodologies (LaMere et al. 2020; Gray et al. 2018; Olazabal et al. 2018; Voinov et al. 2016) prompted us to use an adaptation of Gray et al.'s framework (2018) to break down our methods into the processes, partnerships, and products of our work.

\subsection{Processes: conducting interviews and creating mental models}

Mental model interviews were conducted in Maine and Vermont over six months in 20182019. Across states, we conducted 33 farmer interviews and 16 interviews with "outreach professionals." We define outreach professionals as those who have a role in sharing climate change information with farmers, including Extension professionals, climatologists, agricultural advisors and researchers, and government officials working in agriculture and climate sectors.

Each farmer and outreach professional interview consisted of two parts: a recorded semistructured interview conversation, followed by a computer-based mental model exercise. The process typically took $90 \mathrm{~min}$ per interviewee. Participating farmers were compensated $\$ 50$ for

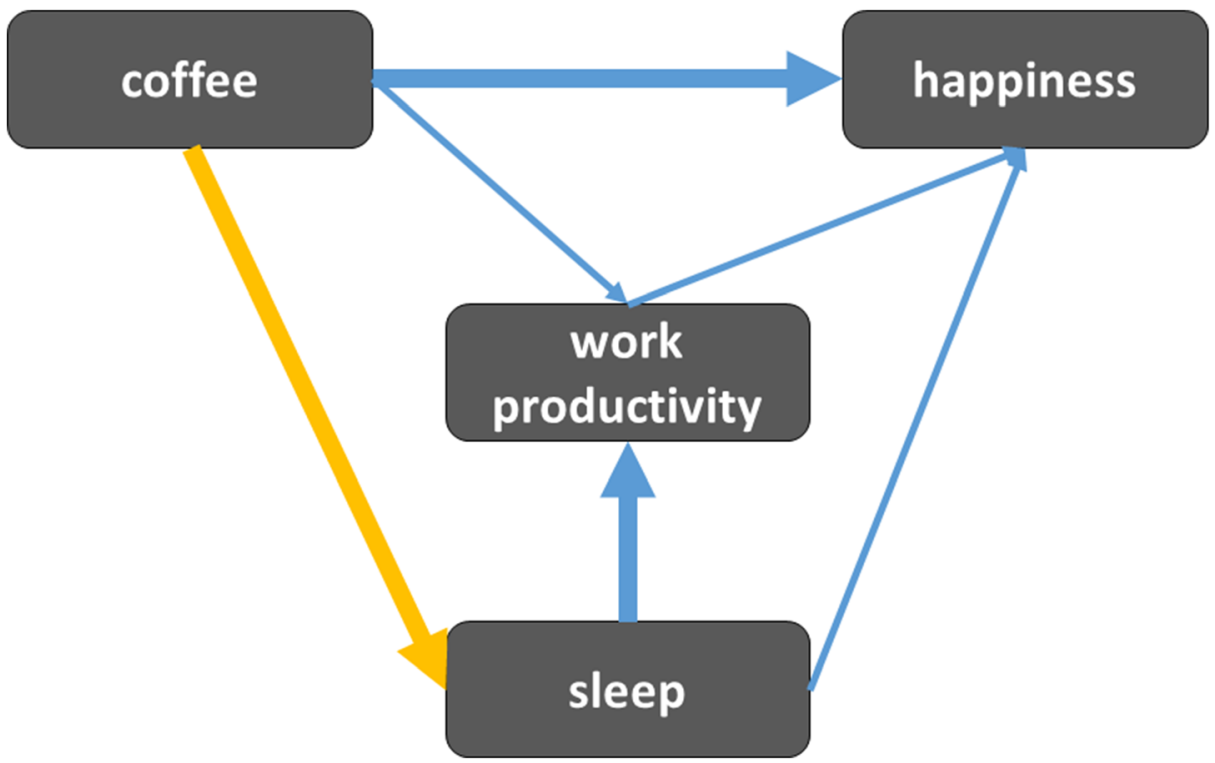

Fig. 1 Example mental model showing concepts a participant might identify related to work productivity, and connections illustrating positive (blue) and negative (orange) relationships they might perceive between these concepts 
their time, as were outreach professionals in Vermont who were able to accept payment. All participants gave their informed consent to participate, following protocols approved by University of Maine and University of Vermont's respective Institutional Review Board offices. Interviews were conducted by four trained facilitators, who followed shared protocols and corresponded frequently in order to minimize facilitator effects.

Each interview began with a semi-structured conversation (Online Resource 1) designed to elucidate participant perspectives on climate change in relation to their farming system. Each conversation followed the same pattern of questioning on agricultural challenges within the participant's state, their climate change perspectives, sources of information on weather and climate-related challenges, and barriers to adoption of practices that could enhance climate resilience. Participant demographic information including age and gender was also collected (Online Resource 2). Recorded interviews were transcribed by a professional transcription service.

Following each semi-structured interview conversation, facilitators worked with participants to create a mental model of a farming system using the software tool "Mental Modeler" (http://www.mentalmodeler.org), following Özesmi and Özesmi (2004). Farmers were prompted to define the key components of their farming system, and explain how those components were connected. Outreach professionals were prompted to do the same for a farm with which they work or were familiar (Online Resource 1). Some participants readily understood the process and engaged in the activity with little prompting. Others required more explanation, which typically included the facilitator demonstrating how to make a simple model of an unrelated system (Fig. 1), then suggesting to participants a generally applicable starting point like "purpose of the farm." To keep mental models at a similar level of detail, we used $30 \mathrm{~min}$ as a target time frame for model completion. This interview format, in which the mental model exercise directly followed a semi-structured conversation about climate resilience, may have "primed" participants to mention climate change during the mental model activity when they would not have otherwise.

\subsection{Partnerships: recruiting farmer and outreach professional participants}

Farmer participants were primarily recruited by email announcements sent through farmer listservs. Some additional recruitment occurred by word of mouth. We interviewed farmers from a range of agricultural sectors important to Maine and Vermont (Table 1). Outreach professionals were selectively invited to participate in order to garner an interview population with a range of expertise related to climate, agricultural science, and farmer engagement (Table 1).

Recruitment materials specified that we were seeking to interview small- to medium-scale or beginning farmers and that the purpose of the project was to learn about participant perspectives on climate change. These materials explicitly encouraged participation from farmers who were military veterans, women, or people of color, as these groups are often underrepresented in agricultural research. Women comprised $40 \%$ of farmer participants. Three farmers were military veterans. One farmer identified as multiracial (white and Native American); all others identified as white. These participant demographics are similar to the farmer demographics of Maine and Vermont (Online Resource 2).

\subsection{Products: data analysis and visualization}

Mental models can be considered individually, or aggregated across multiple stakeholders or groups in order to capture complex community knowledge and perceptions. Either 
Table 1 Interview participant characteristics. Some farmer participants were included in multiple sectors (e.g., a fruit and vegetable farmer would be included in both "Fruit" and "Mixed vegetables")

\begin{tabular}{|c|c|c|c|c|c|c|}
\hline Type & State & Sector & $\begin{array}{l}\text { Participants } \\
\text { (N) }\end{array}$ & $\begin{array}{l}\text { Average } \\
\text { Experience } \\
\text { (years) }\end{array}$ & $\begin{array}{l}\text { Organic } \\
\text { (N) }\end{array}$ & $\begin{array}{l}\text { Farm size } \\
\text { (hectares, } \\
\text { mean } \pm \text { std. error) }\end{array}$ \\
\hline \multirow[t]{12}{*}{ Farmers } & \multirow[t]{6}{*}{$\mathrm{ME}$} & Beef & 3 & 9 & 1 & $57 \pm 23$ \\
\hline & & Other livestock ${ }^{\mathrm{a}}$ & 5 & 11 & 2 & $14 \pm 11$ \\
\hline & & Mixed vegetables & 12 & 9 & 9 & $9 \pm 1$ \\
\hline & & Fruit $^{\mathrm{b}}$ & 5 & 12 & 4 & $12 \pm 3$ \\
\hline & & Potato & 3 & 17 & 0 & $469 \pm 81$ \\
\hline & & Other & 1 & 3 & 0 & 2 \\
\hline & \multirow[t]{6}{*}{ VT } & Beef & 9 & 15 & 2 & $129 \pm 7$ \\
\hline & & Other livestock & 6 & 10 & 2 & $105 \pm 13$ \\
\hline & & Mixed vegetables & 4 & 16 & 2 & $136 \pm 27$ \\
\hline & & Fruit & 2 & 8 & 2 & $168 \pm 53$ \\
\hline & & Maple & 3 & 7 & 0 & $96 \pm 19$ \\
\hline & & Other & 3 & 4 & 0 & $76 \pm 5$ \\
\hline \multirow{9}{*}{$\begin{array}{l}\text { Outreach } \\
\text { professionals }\end{array}$} & \multirow[t]{4}{*}{$\mathrm{ME}$} & Extension & 4 & 36 & N/A & N/A \\
\hline & & $\begin{array}{c}\text { Agricultural } \\
\text { services }^{c}\end{array}$ & 2 & 44 & N/A & N/A \\
\hline & & $\begin{array}{l}\text { Agricultural } \\
\text { research }\end{array}$ & 5 & 35 & N/A & N/A \\
\hline & & Climatology & 2 & 18 & N/A & $\mathrm{N} / \mathrm{A}$ \\
\hline & \multirow[t]{5}{*}{ VT } & Extension & 2 & 12 & N/A & N/A \\
\hline & & $\begin{array}{l}\text { Agricultural } \\
\text { services }\end{array}$ & 1 & 15 & N/A & N/A \\
\hline & & $\begin{array}{l}\text { Agricultural } \\
\text { research }\end{array}$ & 1 & 13 & N/A & N/A \\
\hline & & Climatology & 1 & 22 & N/A & N/A \\
\hline & & Government & 2 & 11 & N/A & N/A \\
\hline
\end{tabular}

a "Other Livestock" includes sheep, poultry, and pork

b "Fruit" includes small fruit and orchards

c "Agricultural services" includes participants who worked as researchers or agricultural advisors outside of academia

individually or in aggregated form, models can be quantitatively and qualitatively compared to elucidate similarities and differences (Özesmi and Özesmi 2004; Jones et al. 2011; Gray et al. 2012; Olazabal et al. 2018). In this study, we constructed aggregate models of farmers and outreach professionals, respectively, in order to compare and understand any differences in the whole-farm management perspectives of these key stakeholder groups (research question 2).

Prior to aggregation and further analysis, concepts in participants' individual mental models were standardized following the methods of Olazabal et al. (2018). One interview facilitator from Vermont and one facilitator from Maine separately coded participants' original concepts into broader categories (e.g., the raw concept "carbon sequestration" was ultimately coded as "environmental stewardship"; see Online Resource 3). Between the two facilitators, $45 \%$ of concepts were coded similarly after the first round of coding. The process was repeated until full agreement was reached between all facilitators on each standardized term. Raw mental models and interview notes were consulted to ensure standardized terms represented original concepts as accurately as possible within the context of each interview. See Online Resource 2 for a glossary of standardized terms.

To determine that the interview sample size was sufficient, we constructed concept accumulation curves of standardized mental model concepts (Özesmi and Özesmi 2004). 
Accumulation curves show the addition of new concepts per interview when interview order is shuffled and re-sampled repeatedly using Monte-Carlo techniques. We constructed curves with 100 random permutations using the vegan package in $\mathrm{R}$ (Oksanen et al. 2019), and observed that curves approached a horizontal asymptote for both participant populations at approximately 10 interviews (Fig. 2), suggesting that few new concepts were being added beyond this number of interviews and our sample populations were therefore of sufficient size.

Following concept standardization, aggregated farmer and outreach professional mental models were created by including all concepts and relationships mentioned by each participant, with arrows depicting the frequency of relationship mentions (Volpato and King 2019). We calculated the number of unique mentions of each concept as the number of participants who included that concept in their individual mental model. The frequency of unique concept mentions in farmer and outreach professional aggregate models were compared using tests of equal or given proportions using default settings in R (R Core Team 2019). Centrality scores for the ten most central concepts in the farmer mental model were compared between farmers and outreach professionals with a nonparametric Wilcoxon/Kruskal-Wallis test.

For visualization purposes, we simplified the aggregated mental models to only include concepts and connections that were mentioned by at least $10 \%$ of farmers (Fig. 3) or outreach professionals (Fig. 4). Aggregated matrices with all concepts and connections may be found in Online Resource 4. Following aggregation, we grouped concepts into five major categories Management, Goals \& Values, Finances \& Economics, Climate \& Weather, and Social \& Intellectual Capital - in order to interpret differences between the mental models on a scale beyond individual concepts. We compared the prevalence of each category in the farmer and outreach professional models using tests of equal or given proportions in R (R Core Team 2019).

Descriptive statistics for the aggregated and individual mental models (Eden et al. 1992; Hage and Harary 1983; Özesmi and Özesmi 2004) were calculated using Mental Modeler software, including total number of concepts; number of driving, receiving, and ordinary concepts; total number of connections; connections per component; model density; model complexity; and concept centrality. Calculations were based on the methods of Özesmi and Özesmi (2004). Driving concepts are defined as those with only outgoing connections, while receiving concepts only have

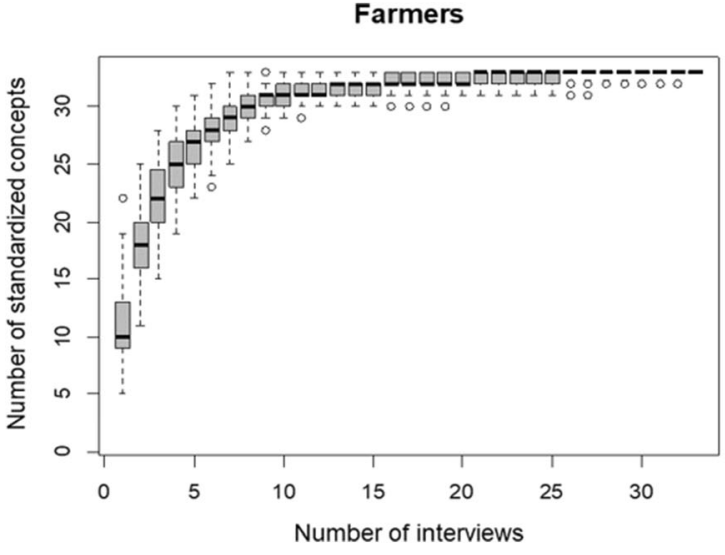

(a)
Outreach Professionals

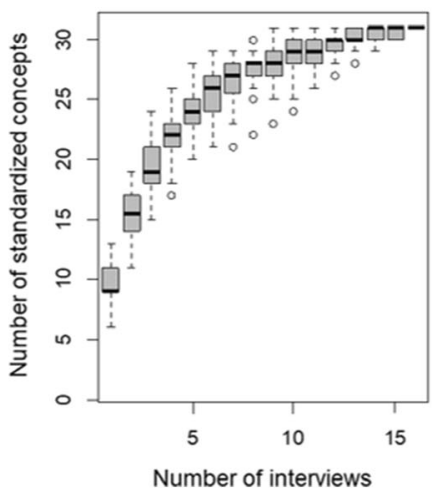

(b)

Fig. 2 Concept accumulation curves for concepts mentioned in (a) farmer and (b) outreach professional interviews. Graphic produced in: R 


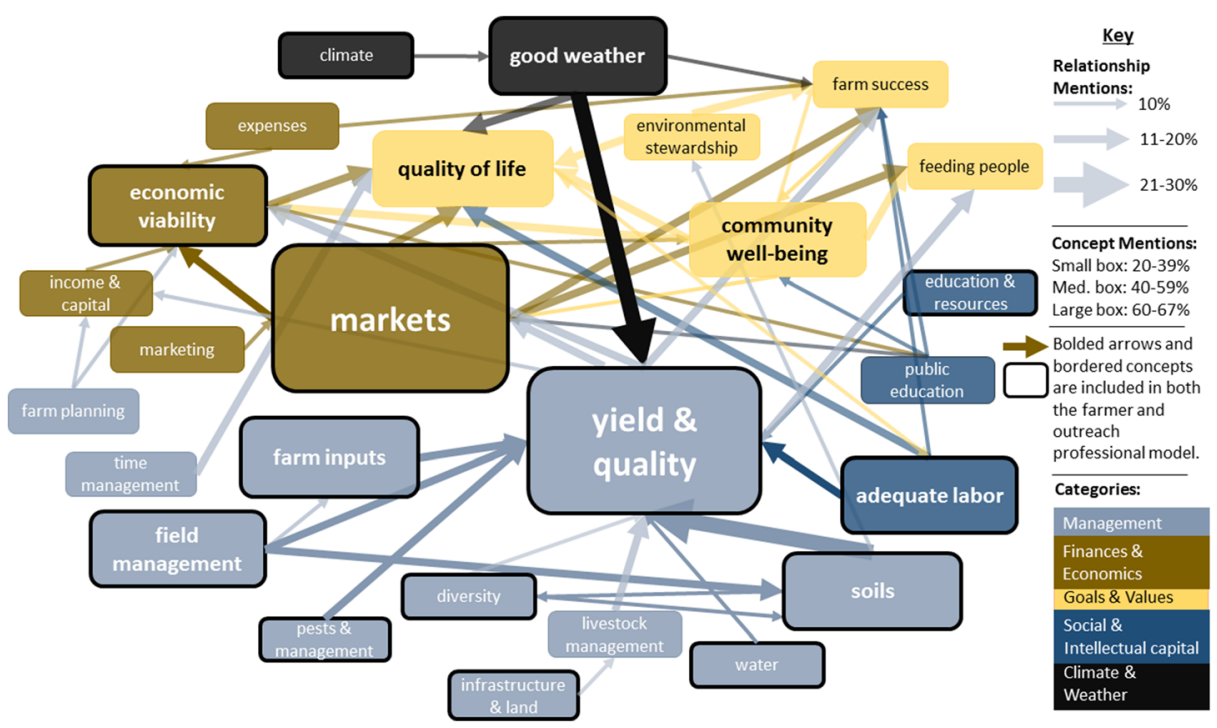

Fig. 3 Aggregated farmer mental model of the concepts and relationships mentioned by $\geq 10 \%$ of farmer participants $(n=33)$; "Relationship Mentions" and "Concept Mentions" reflect the percentage of farmers who included that relationship or concept in their mental model; color indicates the concept category

incoming connections. Model complexity is calculated as the ratio of receiving concepts to driving concepts. Model density is calculated as the number of connections divided by the squared number of variables, used here to measure the connectivity of the mental models. Concept centrality refers to the number and strength of connections going into and out of a concept; the more connections a concept has, the more central it is to the mental model. We considered centrality an indicator of the influence a concept has on the mental model as a whole (Özesmi and Özesmi 2004).

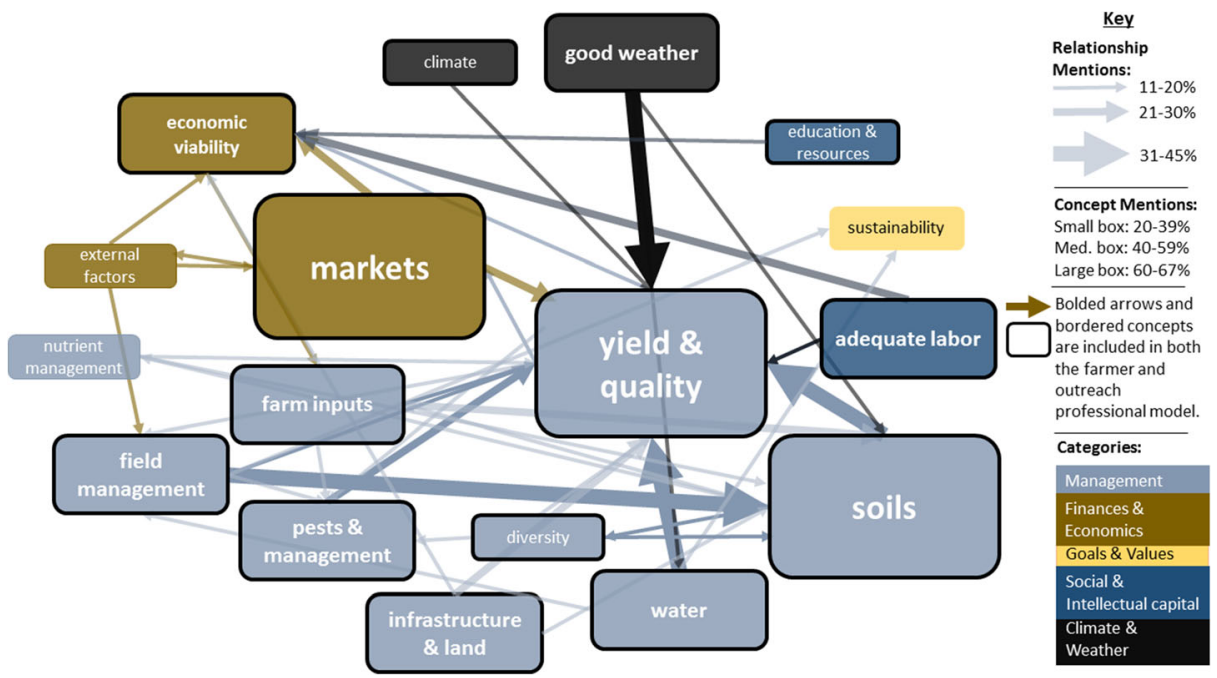

Fig. 4 Aggregated outreach professional mental model of the concepts and relationships mentioned by $\geq 10 \%$ of outreach professional participants $(n=16)$; "Relationship Mentions" and "Concept Mentions" reflect the percentage of outreach professionals who included that relationship or concept in their mental model; color indicates the concept category 
To assess the importance of climate change in relation to participants' whole-farm perspectives (research question 1), we scored how early participants mentioned climate change during their semi-structured interviews. These mention scores (1-5) refer to which question number elicited each participant's first mention of climate change, where questions 1-4 asked about general agricultural perspectives, and question 5 was the first question asking about climate change explicitly (Online Resource 1). An ANCOVA model constructed in R (R Core Team 2019) was used to test for effects of the demographic characteristics age, gender, race, and veteran status on the response variable mention score, and a separate ANCOVA model was used to test for effects of the farm characteristics years' experience, acres, organic status, and nonprofit status on mention score.

\section{Results}

\subsection{Aggregate farmer mental model}

The aggregate farmer mental model contained 27 total concepts; $24 \%$ of farmers $(n=8)$ explicitly included climate in their mental model, while $45 \%$ included good weather $(n=15)$ (Table 2). Over $50 \%$ of farmers mentioned the concepts markets $(n=22)$, yield \& quality $(n=$ $21)$, adequate labor $(n=18)$, economic viability $(n=18)$, and community well-being $(n=18)$. Of the major categories we identified, Management was the largest category in the farmer model, containing $42 \%$ of the total number of concepts mentioned by farmers (Table 2). Climate \& Weather was the smallest category with $6 \%$ of concepts. The two most frequently mentioned relationships in the farmer mental model were from soils to yield \& quality $(n=9)$ and from good weather to yield \& quality $(n=9)$ (Fig. 3).

\subsection{Aggregate outreach professional mental model}

The aggregate outreach professional model included 17 total concepts; $25 \%$ of outreach professionals included climate in their mental model $(n=4)$, while $44 \%$ included good weather $(n=7)$ (Table 2). Over $50 \%$ of outreach professionals mentioned the concepts markets $(n=$ $12)$, yield \& quality $(n=12)$, soils $(n=10)$, adequate labor $(n=9)$, economic viability $(n=9)$, and field management $(n=9)$. Management was the largest category in the outreach professional model and Climate \& Weather was the smallest (Table 2). The most frequently mentioned relationship in the aggregate outreach professional mental model (Fig. 4) was from soils to yield \& quality $(n=7)$.

\subsection{Model comparisons}

In the aggregated farmer mental model, climate was solely a direct driver of good weather, which was in turn a driver of yield \& quality, farm success, and quality of life (Fig. 3). In contrast, the aggregated outreach professional mental model included a direct relationship between climate and yield \& quality (Fig. 4). Good weather was also a driver of yield \& quality, as well as soils and water in the outreach professional model.

The proportion of mental model concepts grouped under the Goals \& Values category was greater in the aggregate farmer model than the aggregate outreach professional model $(P<0.05)$ (Table 2$)$. The proportion of farmers who mentioned the standardized concepts 
Table 2 Categories and concepts mentioned in the farmer and outreach professional aggregated mental models (MM). Concepts are organized by category

\begin{tabular}{|c|c|c|c|c|c|}
\hline \multicolumn{3}{|l|}{ Concept categories } & \multicolumn{3}{|c|}{ Unique concept mentions } \\
\hline Category & $\begin{array}{l}\text { Concepts in farmer } \\
\mathrm{MM}(\%)^{\mathrm{a}}\end{array}$ & $\begin{array}{l}\text { Concepts in } \\
\text { outreach } \\
\text { professional } \\
\text { MM }(\%)\end{array}$ & Concepts & $\begin{array}{l}\text { Farmers } \\
(\%)^{\mathrm{b}}\end{array}$ & $\begin{array}{l}\text { Outreach } \\
\text { professionals }(\%)\end{array}$ \\
\hline \multirow[t]{15}{*}{ Management } & \multirow[t]{15}{*}{42} & \multirow[t]{15}{*}{50} & Yield \& quality & 64 & 75 \\
\hline & & & Field management & 48 & 56 \\
\hline & & & Soils & 42 & 63 \\
\hline & & & Farm inputs & 42 & 38 \\
\hline & & & $\begin{array}{l}\text { Infrastructure } \\
\text { \& land }\end{array}$ & 36 & 50 \\
\hline & & & $\begin{array}{l}\text { Pests \& } \\
\quad \text { management }\end{array}$ & 33 & 44 \\
\hline & & & $\begin{array}{l}\text { Livestock } \\
\text { management }\end{array}$ & 33 & 13 \\
\hline & & & Diversity & 30 & 25 \\
\hline & & & Water & 27 & 44 \\
\hline & & & $\begin{array}{l}\text { General } \\
\text { management }\end{array}$ & 27 & 19 \\
\hline & & & Farm planning & 27 & 13 \\
\hline & & & $\begin{array}{l}\text { Postharvest } \\
\text { management }\end{array}$ & 21 & 6 \\
\hline & & & Time management & 21 & 6 \\
\hline & & & Technology & 9 & 6 \\
\hline & & & $\begin{array}{l}\text { Nutrient } \\
\text { management }\end{array}$ & 6 & 25 \\
\hline \multirow{7}{*}{$\begin{array}{l}\text { Finances \& } \\
\text { Economics }\end{array}$} & \multirow[t]{7}{*}{21} & \multirow[t]{7}{*}{24} & Markets & 67 & 69 \\
\hline & & & Economic viability & 55 & 56 \\
\hline & & & Expenses & 33 & 6 \\
\hline & & & Marketing & 30 & 13 \\
\hline & & & Income capital & 27 & 13 \\
\hline & & & $\begin{array}{l}\text { Pro-ag policy } \\
\quad \& \text { regulation }\end{array}$ & 18 & 31 \\
\hline & & & External forces & $3 *$ & 38 \\
\hline \multirow[t]{6}{*}{ Goals \& Values } & \multirow[t]{6}{*}{$20 *$} & \multirow[t]{6}{*}{8} & $\begin{array}{l}\text { Community } \\
\text { well-being }\end{array}$ & $55^{*}$ & 19 \\
\hline & & & Quality of life & 45 & 25 \\
\hline & & & $\begin{array}{c}\text { Environmental } \\
\text { stewardship }\end{array}$ & 39 & 19 \\
\hline & & & Farm success & $36^{*}$ & 0 \\
\hline & & & Feeding people & 27 & 13 \\
\hline & & & Sustainability & 21 & 25 \\
\hline \multirow{3}{*}{$\begin{array}{l}\text { Social \& } \\
\text { Intellectual } \\
\text { Capital }\end{array}$} & \multirow[t]{3}{*}{11} & \multirow[t]{3}{*}{8} & Adequate labor & 55 & 56 \\
\hline & & & $\begin{array}{c}\text { Education \& } \\
\text { resources }\end{array}$ & 39 & 25 \\
\hline & & & Public education & $30 *$ & 0 \\
\hline \multirow[t]{2}{*}{ Climate \& Weather } & \multirow[t]{2}{*}{6} & \multirow[t]{2}{*}{7} & Good weather & 45 & 44 \\
\hline & & & Climate & 24 & 25 \\
\hline
\end{tabular}

a Percent of total concepts in each aggregated mental model that belong to each category

$\mathrm{b}$ Percent of participants who mentioned each concept in their own mental model

$*=P<0.05$ 
community well-being $(P=0.04)$, farm success $(P=0.02)$, and public education $(P=0.04)$ in their mental models was also greater than the proportion of outreach professionals (Table 2$)$. In contrast, more outreach professionals mentioned external forces $(P=0.01)$ in their mental models than farmers. Among the 10 most central concepts in the aggregated farmer mental model, four had significantly higher centrality scores than in the outreach professional mental model (Fig. 5): community well-being $(P<0.05)$, environmental stewardship $(P<0.05)$, quality of life $(P<0.05)$, and farm success $(P<0.05)$.

Farmers had a greater number of concepts in their aggregated mental model (27) than outreach professionals (17), but included fewer connections between them overall, with a model density of 0.07 compared to 0.15 for outreach professionals (Table 3 ). Both aggregate models had only one true receiver concept (feeding people in the farmer model, sustainability in the outreach professional model). The farmer model had 11 driver concepts while the outreach professional model had 5 drivers, leading farmers to have a lower overall complexity score (0.09). Climate, infrastructure \& land, and education \& resources were drivers in both the farmer and outreach professional models. Additional outreach professional model drivers were adequate labor and good weather. Additional farmer model drivers were expenses, farm planning, field management, marketing, pest management, public education, time management, and water.

How early farmers and outreach professionals mentioned climate change in their interviews was not predicted by participant age, gender, race, or veteran status $\left(\mathrm{R}^{2}=0.12, \mathrm{~F}=0.70, P=\right.$ $0.60)$, nor by the farm-related characteristics acres, years of experience, organic status, or nonprofit status $\left(\mathrm{R}^{2}=0.18, \mathrm{~F}=0.68, P=0.62\right)$.

\section{Discussion}

This study compared mental models created with small to medium-scale and beginning farmers in Maine and Vermont to those of outreach professionals. Our goals were to

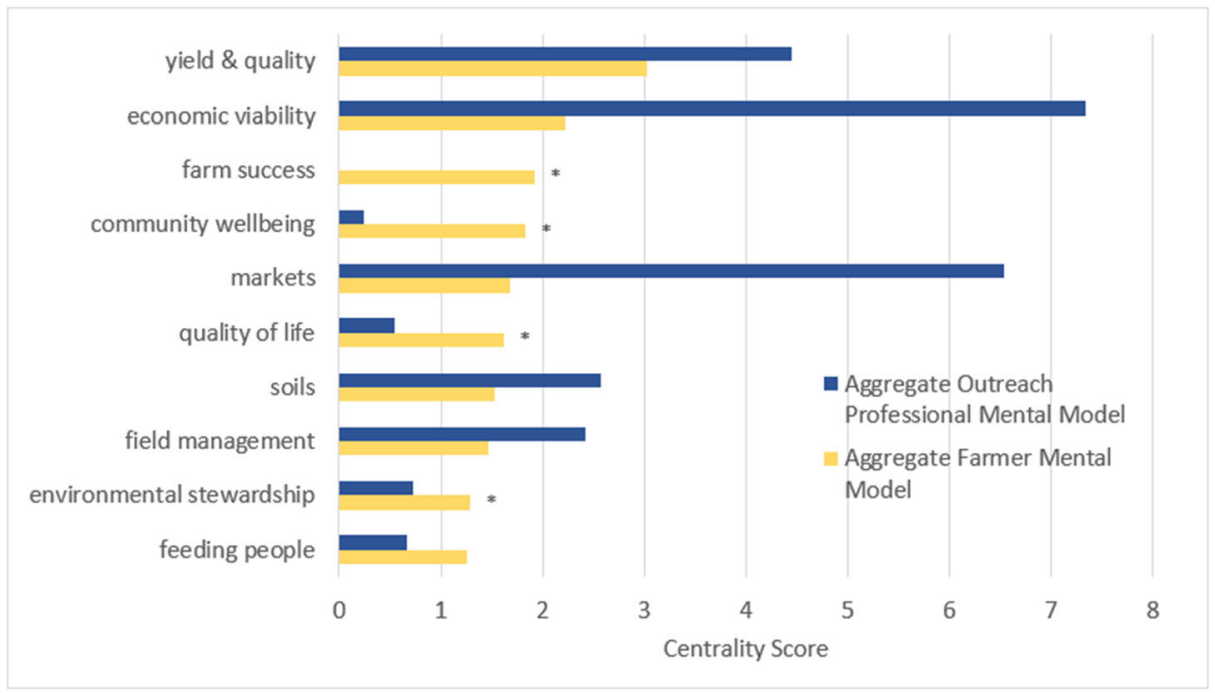

Fig. 5 Centrality score (the measure of influence a concept has on the mental model) comparison between farmers and outreach professionals for the ten most central concepts in the aggregated farmer mental model; * = $P<0.05$ 
Table 3 Descriptive statistics summary of the farmer and outreach professional mental models

\begin{tabular}{llllll}
\hline & \multicolumn{2}{l}{ Aggregate model $^{\mathrm{a}}$} & & \multicolumn{2}{l}{ Individual models $^{\mathrm{b}}$} \\
\cline { 2 - 3 } \cline { 5 - 6 } & Farmers & Outreach Prof. & & Farmers & Outreach Prof. \\
\hline Total concepts & 27 & 17 & $11(5-22)$ & $10(6-13)$ \\
Total connections & 52 & 41 & & $17(4-40)$ & $15(1-29)$ \\
Density & 0.07 & 0.15 & & $0.15(0.07-0.28)$ & $0.2(0.02-0.97)$ \\
Drivers & 11 & 5 & $1(0-10)$ & $3(0-7)$ \\
Receivers & 1 & 1 & $0.5(0-4)$ & $1(0-2)$ \\
Complexity score & 0.09 & 0.2 & & $0.45(0-1)$ \\
\hline
\end{tabular}

a After removing concepts and connections mentioned by fewer than $10 \%$ of participants

${ }^{\mathrm{b}}$ Individual summary lists mean and range of all respondents

understand how climate change fits within the whole-farm management perspectives of these stakeholder groups, identify any key differences between farmer and outreach professional conceptions of climate change or farming systems, and use this information to suggest opportunities to improve outreach on climate resilience for farmers.

\subsection{Climate change and whole-farm management perspectives}

We hypothesized that climate would not be central to farmer mental models (H1). Despite being primed to think about climate change during the semi-structured interview conversations, less than one-quarter of farmers included a direct mention of climate change, or climate itself, in their mental models, in line with H1. Notably, all participants indicated a belief that the climate is changing, and all participants mentioned experiencing effects of climate change on their farm. That only a minority included the concept in their mental models suggests that participants may have perceived climate change to have little direct impact on the key components and processes within their farming systems compared to more specific weatherrelated problems (see Online Resource 3 for coding of weather vs climate). This is in keeping with the findings of Jones et al. (2017) that climate change is often perceived as "psychologically distant" in ways that diminish its perceived relevance to daily life. Farmer participants may have also felt less certain about the impacts of climate change compared to short-term weather impacts on their farm, as found in a previous study among Maine farmers (Jemison et al. 2014). During the semi-structured interviews, one farmer noted,

"When we're looking at something like climate change. . . we know that it exists and it's real, but we don't know what that means and what it's gonna do."

\subsection{Key differences between farmer and outreach professional perspectives}

Differences in how farmers and outreach professionals included human and social components in their mental models provided a key distinction between the two groups' perspectives, consistent with H2. Where outreach professionals perceived that changes in weather would mainly impact biophysical farm management factors (Fig. 4), farmers also perceived direct connections between weather, their quality of life, and their ability to achieve success on their farm (Fig. 3). Here, quality of life includes mentions of physical and mental well-being, providing some support for the recent finding that weather variability is among the four most 
influential factors affecting farmer mental health in the USA (Daghagh Yazd et al. 2019). Farm success included concepts farmers mentioned as critical goals or missions of their farm, such as providing for themselves, their families, or preserving the farm for future generations (Online Resource 3).

Differences in key concepts between the models further indicate that sociocultural factors play a larger role in farmers' perceptions of their farming systems than outreach professionals'. Among concept categories, Goals \& Values showed the greatest difference between models (Table 2); $20 \%$ of concepts in the aggregate farmer model belonged to this category, compared to $8 \%$ of concepts in the aggregate outreach professional model. Within Goals \& Values, community well-being and quality of life were mentioned by the most farmers (Table 2). Farmers also perceived community well-being, quality of life, environmental stewardship, and farm success as having higher influence on their farming system than outreach professionals did, indicated by each concept's centrality score (Fig. 5). Alternatively, while not a statistically significant difference, outreach professionals generally perceived markets and economic viability as largely more influential concepts than farmers (Fig. 5), indicating a further difference in perceived priorities between the groups.

In one interview before the mental modeling exercise, a farmer noted the following in regard to community well-being:

"I do think there's potential for us to feed our communities and to help each other out. .

I think that the strength and comradery in our communities of different scales is really

impressive and something I'm proud of and continually working on maintaining along with a lot of other people."

Community well-being was also present in mental models of sustainable agriculture among wine grape growers in California, USA, but at much lower frequencies relative to the mental models in this study (Hoffman et al. 2014). Many factors could play a role in the different influences these concepts have in different farmer's mental models, and outreach work should not assume that important concepts for one group of farmers will be similarly important for another. However, our findings do reinforce the claim that values and goals influence farmer decision-making; specifically, that when faced with a problem, farmers may evaluate how potential solutions align with their values or help them achieve their on-farm goals (Ohlmer et al. 1997).

Structural characteristics of the aggregated mental models also revealed key differences between participant groups (Table 3). The outreach professional mental model had more relationships per concept than the farmer mental model, leading to a higher density score, and fewer true driving concepts, resulting in a higher complexity score (Table 3). These structural differences suggest that the outreach professional group may see more opportunities for change within farming systems (Özesmi and Özesmi 2004), as evidenced by the higher number of perceived causal relationships. These results are consistent with Halbrendt et al.'s (2014) findings that aggregated scientific expert models had higher densities and complexities than aggregated farmer mental models. Notably, individual farmer mental models had a slightly greater mean complexity than individual outreach professionals' in our study (Table 3), highlighting the potential for changes in mental model structure between individual and aggregated models. This could also have implications for incorporating systems thinking into outreach approaches, as farmers who displayed greater levels of systems thinking and perceived more interconnections within their farming systems were also more likely to have adopted cover cropping practices in one study (Church et al. 2020). 


\subsection{Implications for climate change outreach}

Understanding opportunities for improved outreach and communication related to climate change was a key goal of this study (research question 3), and our two key findings highlight many potential opportunities for climate outreach. First, that only a minority of farmers included climate in their mental models of their farm systems, despite all of them believing in climate change, suggests that farmers are similar to the general public in that climate change is a priority, but does not rank as highly as other priorities in the day-to-day thinking of farming systems. In practice, this suggests that climate change outreach may best be delivered not specifically as "climate change materials" or interventions, but rather that climate change should be integrated across outreach and technical assistance efforts in all aspects of farming systems, including economic, social, and environmental farm management concerns. In addition, clarifying the connections between climate and more variable weather could help build farmers' understanding that weather-related challenges will likely become more frequent and severe in the future (see Wolfe et al. 2018). Delivering this information among agricultural advisors who farmers most trust, may also be impactful in this space (Arbuckle et al. 2015).

Second, the emphasis on community, personal, and environmental well-being expressed by farmers in our interviews has implications for how agricultural outreach, including outreach on climate adaptation and resilience, is presented by researchers and advisors. Framing outreach to build clear connections between climate adaptive practices and factors that farmers perceive to help them achieve success on their farm, such as their quality of life or community relationships, could be an opportunity to improve adoption (Jew et al. 2020). Research as to how quality of life, community well-being, and sense of environmental stewardship may interact with farmers' perceived capacity to implement new practices, a strong influence on actual practice adoption (Niles et al. 2016; Doran et al. 2020), could provide valuable insights for professionals seeking to strengthen farmer outreach. We propose potential action steps to incorporate these social and human dimensions into agricultural climate change outreach and communication, presented in Table 4.

The relationships between farmers and the communities around them are also an important facet of farming systems highlighted in our results (Fig. 3). In our semi-structured interviews, multiple farmers stressed the importance of public education to their farm success and quality of life, stating that they would feel better supported by their communities — both financially and socially - if consumers better understood the cost of producing food on small to mediumscale operations like theirs. One farmer summarized:

"We need to throw back the curtain on the real cost of food. . People need to be educated."

We suggest that broadening the scope of agricultural outreach to explicitly include social sustainability (WCED 1987; Vallance et al. 2011) as a goal to work towards with farmers, alongside economic and environmental sustainability, should be a priority shared by outreach providers, institutions, and funding agencies alike (Tobin et al. 2017; Birthisel et al. 2020), with specific examples suggested in Table 4.

The direct relationships farmers perceived between weather and both biophysical and human-dimensions components of their farming systems support a need for interdisciplinary climate outreach teams (Table 4). Collaborating with rural sociologists, for example, could help technical outreach professionals build connections between their areas of expertise and complex sociocultural issues, such as quality of life and community well-being, in farmer 
Table 4 Avenues for incorporating social dimensions into agricultural outreach by individual providers, institutions, and funding agencies

\begin{tabular}{|c|c|c|}
\hline Outreach group & Recommended action steps & Potential examples \\
\hline $\begin{array}{l}\text { Individual outreach } \\
\text { professionals }\end{array}$ & $\begin{array}{l}\text { Explicitly outline the social dimensions of } \\
\text { research and demonstration projects } \\
\text { during planning and implementation } \\
\text { phases (Takemura et al. 2014). }\end{array}$ & $\begin{array}{l}\text { A project on introducing a new crop variety } \\
\text { utilizes farmer-to-farmer training events } \\
\text { to share new information among the lo- } \\
\text { cal agricultural community, helping } \\
\text { build social capital and leadership } \\
\text { among participants (Taylor and Bhasme } \\
\text { 2018). }\end{array}$ \\
\hline $\begin{array}{l}\text { Institutions \& } \\
\text { organizations } \\
\text { providing outreach } \\
\text { services }\end{array}$ & $\begin{array}{l}\text { - Provide training for providers to help } \\
\text { farmers identify and work towards their } \\
\text { own goals for their farm (Knook et al. } \\
\text { 2020). } \\
\text { - Hire professionals with relevant } \\
\text { sociocultural expertise to join outreach } \\
\text { teams (Tanaka \& Bhavar 2008). }\end{array}$ & $\begin{array}{l}\text { Outreach professionals are provided with a } \\
\text { step-by-step toolkit, such as Supporting } \\
\text { Relationships for Farm Success } \\
\text { (Forstadt 2019), on communicating with } \\
\text { farmers about their goals. }\end{array}$ \\
\hline Funding agencies & $\begin{array}{l}\text { Require social dimension considerations in } \\
\text { agricultural outreach and research grant } \\
\text { proposals, and establish a formal } \\
\text { category for evaluating the social } \\
\text { impacts of a proposal during grant } \\
\text { reviews (Tanaka \& Bhavar 2008). }\end{array}$ & $\begin{array}{l}\text { Funding agency evaluates a proposal's } \\
\text { impact on quality of life within the } \\
\text { relevant community by developing a set } \\
\text { of quality of life measures, such as those } \\
\text { developed by Tanaka and Bhavar (2008) } \\
\text { that include trust, collaboration, } \\
\text { leadership, and entrepreneurship. }\end{array}$ \\
\hline
\end{tabular}

outreach (Tanaka and Bhavsar 2008). Further, interdisciplinarity is a key principle of coproducing knowledge and resources between scientists and stakeholders (Meadow et al. 2015), exemplified by the recent "Useful to Useable" climate information co-production project between farmers and outreach professionals across multiple disciplines (Prokopy et al. 2017).

While there are many more ways in which outreach professionals may incorporate social dimensions of farming in their work, building trusted relationships between farmers, community members, and researchers is an important foundation (Takemura et al. 2014; Tanaka and Bhavsar 2008). Scientist and stakeholder co-production of climate adaptation solutions is one potential pathway for building these relationships, and is growing in use as a process for climate resilience research (Bremer and Meisch 2017; Prokopy et al. 2017; Meadow et al. 2015). Understanding stakeholder perceptions, and how they may differ from outreach professionals' (Halbrendt et al. 2014), can pave the way for effective communication as outreach professionals and stakeholders work together to produce effective adaptation solutions (Meadow et al. 2015.; Bremer and Meisch 2017; Ranjan et al. 2019; Birthisel et al. 2020; Kingiri 2020). Our findings suggest that framing climate communication in terms of impacts to community, environmental, and personal well-being may facilitate climate adaptation outreach for small to medium-scale farmers in northern New England. We hope this study will provide insights for future research to move beyond consulting farmers to partnering with farmers (Arnstein 1969) in codeveloping resources and strategies to build agricultural climate resilience.

\subsection{Limitations of study}

Our sample size (33 farmers and 16 outreach professionals) was sufficient to construct and compare mental models (Fig. 2) but was too small to allow robust subpopulation analyses based on participant demographics. Thus, the inferences we could draw related to 
demographic and farm characteristics - such as age, gender, ethnicity, experience, farm acres, organic status, and whether the farm was a nonprofit - were limited and more work is needed to determine how these factors relate to stakeholder and outreach professional mental models.

\section{Conclusion}

We used mental modeling interviews to understand how farmers and outreach professionals view climate change within the context of whole-farming systems in northern New England. Key takeaways of this study include (1) despite being interviewed about climate change and agriculture prior to mental model elicitation, a minority of farmers and outreach professionals included climate directly in their mental models, (2) farmers perceived that good weather would impact farm management as well as their quality of life and overall success of their farm, while outreach professionals only perceived relationships between weather and biophysical farm management factors, (3) significantly more farmers included community well-being, public education, and farm success in their mental models than did outreach professionals, and (4) within their mental models, farmers perceived community well-being, quality of life, achieving their own definition of farm success, and environmental stewardship as having more influence on their farming system than outreach professionals did. Overall, we conclude that small to medium-scale and beginning farmers in New England valued the human and social dimensions of farming systems more highly than outreach professionals perceived, and that this difference should be incorporated into future climate outreach. Further, these findings support that climate change outreach and technical assistance may best be delivered by embedding it into other aspects of farming system planning that farmers may be more likely to prioritize as compared to climate change, such as weather-related challenges, yield changes, or overall quality of life. Finally, the interconnectedness of climate and weather with environmental, financial, and social factors in the farmer mental model suggests that interdisciplinary outreach teams may aid in successfully addressing farmers' needs and concerns regarding climate adaptation and building climate resilience.

Supplementary Information The online version contains supplementary material available at https://doi.org/ 10.1007/s10584-021-03101-4.

Acknowledgements Many thanks to the farmers and outreach professionals who participated in our interviews. We extend special gratitude to Rachel Schattman for her work in revising this manuscript, and Joshua Faulkner for sharing his perspectives as an outreach professional. We also thank Beth Holtzman, Stephanie Hurley, Tori Jackson, Erin Lane, and V. Ernesto Mendez for their engagement and feedback on this project, and for their help in recruiting interview participants.

Author contribution Niles, Daigneault, Gallandt, and Birthisel led the study's conception and design. Birthisel, Clements, Johnson, Niles, and Wentworth facilitated farmer and outreach professional interviews and collaborated on mental model standardization. Clements and Birthisel lead data analysis and interpretation, and codrafted the Methods section of the manuscript. Clements drafted the remaining manuscript sections. Clements and Birthisel led draft revisions, with all authors contributing to the revision process.

Funding This work was supported by the (1) United States Department of Agriculture (USDA) National Institute of Food and Agriculture (NIFA) Agriculture and Food Research Initiative (Niles, 2018-68006-28098). 
Title: "Assessing climate perceptions and developing adaptation resources for small, medium and beginning farmers", and (2) the USDA NIFA Hatch Project "Efficacy and sustainability of seedling- vs. seed-focused weed management" (Gallandt, Accession Number 1006745; Project Number ME021606), Maine Agricultural and Forest Experiment Station Publication Number XXXXX.

Data availability The standardized, aggregated mental model matrices, the original concepts included in both group's mental models, and the interview questionnaire that preceded the mental modeling exercise are provided as online resources.

\section{Declarations}

This research was approved by the University of Maine and University of Vermont's Institutional Review Boards. We provided each participant with a written informed consent form prior to each interview.

Conflict of interest The authors declare no competing interests.

Open Access This article is licensed under a Creative Commons Attribution 4.0 International License, which permits use, sharing, adaptation, distribution and reproduction in any medium or format, as long as you give appropriate credit to the original author(s) and the source, provide a link to the Creative Commons licence, and indicate if changes were made. The images or other third party material in this article are included in the article's Creative Commons licence, unless indicated otherwise in a credit line to the material. If material is not included in the article's Creative Commons licence and your intended use is not permitted by statutory regulation or exceeds the permitted use, you will need to obtain permission directly from the copyright holder. To view a copy of this licence, visit http://creativecommons.org/licenses/by/4.0/.

\section{References}

Ahearn MC (2011) Potential challenges for beginning farmers and ranchers. Choices: Mag Food, Farm Resource 26(2)

Ahearn, M., and Newton, D. (2009). Beginning farmers and ranchers. Economic information bulletin number 53. Economic Research Service, United States Department of Agriculture. https://permanent.access.gpo.gov/ websites/www.ers.usda.gov/media/156049/eib53_1_.pdf

Arbuckle JG, Morton LW, Hobbs J (2015) Understanding farmer perspectives on climate change adaptation and mitigation: the roles of trust in sources of climate information, climate change beliefs, and perceived risk. Environ Behav 47(2):205-234. https://doi.org/10.1177/0013916513503832

Arnstein SR (1969) A ladder of citizen participation. J Am Inst Plann 35(4):216-224. https://doi.org/10.1080/ 01944366908977225

Austin EJ, Willock J, Deary IJ, Gibson GJ, Dent JB, Edwards-Jones G, Morgan O, Grieve R, Sutherland A (1998) Empirical models of farmer behaviour using psychological, social and economic variables. Part I: linear modelling. Agric Syst 58(2):203-224. https://doi.org/10.1016/S0308-521X(98)00066-3

Birthisel SK, Eastman BA, Soucy AR, Paul M, Clements RS, White A, Acquafredda MP, Errickson W, Zhu LH, Allen MC, Mills SA, Dimmig G, Dittmer KM (2020) Convergence, continuity, and community: a framework for enabling emerging leaders to build climate solutions in agriculture, forestry, and aquaculture. Clim Chang 162(4):2181-2195. https://doi.org/10.1007/s10584-020-02844-w

Bremer S, Meisch S (2017) Co-production in climate change research: reviewing different perspectives. Wiley Interdiscip Rev Clim Chang 8(6):e482. https://doi.org/10.1002/wcc.482

Brown B, Nuberg I, Llewellyn R (2018) Further participatory adaptation is required for community leaders to champion conservation agriculture in Africa. Int J Agric Sustain 16(3):286-296. https://doi.org/10.1080/ 14735903.2018 .1472410

Chatrchyan AM, Erlebacher RC, Chaopricha NT, Chan J, Tobin D, Allred SB (2017) United States agricultural stakeholder views and decisions on climate change. Wiley Interdiscip Rev Clim Chang 8(5):e469. https:// doi.org/10.1002/wcc.469

Church SP, Lu J, Ranjan P, Reimer AP, Prokopy LS (2020) The role of systems thinking in cover crop adoption: implications for conservation communication. Land Use Policy 94:104508. https://doi.org/10.1016/j. landusepol.2020.104508 
Craik K (1943) The nature of explanation. Cambridge University Press, Cambridge

Daghagh Yazd S, Wheeler SA, Zuo A (2019) Key risk factors affecting farmers' mental health: a systematic review. Int J Environ Res Public Health 16(23):4849. https://doi.org/10.3390/ijerph16234849

Demenois J, Torquebiau E, Arnoult MH, Eglin T, Masse D, Assouma MH, Blanfort V, Chenu C, Chapuis-Lardy L, Medoc J-M, Sall SN (2020) Barriers and strategies to boost soil carbon sequestration in agriculture. Front Sustain Food Syst 4. https://doi.org/10.3389/fsufs.2020.00037

Doran EMB, Zia A, Hurley SE, Tsai Y, Koliba C, Adair C, Schattman RE, Rizzo DM, Méndez VE (2020) Social-psychological determinants of farmer intention to adopt nutrient best management practices: implications for resilient adaptation to climate change. J Environ Manag 276:111304. https://doi.org/10.1016/j. jenvman.2020.111304

Eden C, Ackermann F, Cropper S (1992) The analysis of cause maps. J Manag Stud 29(3):309-324. https://doi. org/10.1111/j.1467-6486.1992.tb00667.x

Edwards-Jones G (2006) Modelling farmer decision-making: concepts, progress and challenges. Anim Sci 82(6): 783-790. https://doi.org/10.1017/ASC2006112

Eitzinger A, Binder CR, Meyer MA (2018) Risk perception and decision-making: do farmers consider risks from climate change? Clim Chang 151(3):507-524. https://doi.org/10.1007/s10584-018-2320-1

Fernandez IJ, Schmitt CV, Birkel SD, Stancioff E, Pershing AJ, Kelley JT, Runge JA, Jacobson GL, Mayewski PA (2020) Maine's climate future: 2015 Update. University of Maine, Orono, p 24

Findlater KM, Donner SD, Satterfield T, Kanklikar M (2018a) Integration anxiety: the cognitive isolation of climate change. Glob Environ Chang 50:176-189

Findlater KM, Satterfield T, Kandlikar M, Donner SD (2018b) Six languages for a risky climate: how farmers react to weather and climate change. Clim Chang 148:451-465

Forstadt L (2019) Supporting relationships for farm success: a toolkit for agricultural service providers. The University of Maine Cooperative Extension

Gareau BJ, Huang X, Gareau TP (2018) Social and ecological conditions of cranberry production and climate change attitudes in New England. PLoS One 13:e0207237. Available at. https://doi.org/10.1371/journal. pone. 0207237

Government Accountability Office (GAO). (2007). Beginning farmers: additional steps needed to demonstrate the effectiveness of USDA assistance. United States Government Accountability Office. https://www.gao. gov/new.items/d071130.pdf

Gray S, Chan A, Clark D (2012) Modeling the integration of stakeholder knowledge in social-ecological decision-making: benefits and limitations to knowledge diversity. Ecol Model 229:88-96

Gray S, Voinov A, Paolisso M, Jordan R, BenDor T, Bommel P, Glynn P, Hedelin B, Hubacek K, Introne J, Kolagani N, Laursen B, Prell C, Schmitt Olabisi L, Singer A, Sterling E, Zellner M (2018) Purpose, processes, partnerships, and products: four Ps to advance participatory socio-environmental modeling. Ecol Appl 28(1):46-61. https://doi.org/10.1002/eap.1627

Haden VR, Niles MT, Lubell M, Perlman J, Jackson LE (2012) Global and local concerns: what attitudes and beliefs motivate farmers to mitigate and adapt to climate change? PLoS One 7(12):e52882. https://doi.org/ 10.1371/journal.pone.0052882

Halbrendt J, Gray SA, Crow S, Radovich T, Kimura AH, Tamang BB (2014) Differences in farmer and expert beliefs and the perceived impacts of conservation agriculture. Glob Environ Chang 28:50-62

Hage P, Harary F (1983) Structural models in anthropology. Cambridge University Press

Haigh T, Morton LW, Lemos MC, Knutson C, Prokopy LS, Lo YJ, Angel J (2015) Agricultural advisors as climate information intermediaries: exploring differences in capacity to communicate climate. Weather, Climate, Soc 7(1):83-93. https://doi.org/10.1175/WCAS-D-14-00015.1

Hansen, J., Marx, S., and Weber, E. (2004). The role of climate perceptions, expectations, and forecasts in farmer decision making: final report of an IRI seed grant project. International Research Institute for Climate Prediction. https://iri.columbia.edu/ jhansen/RoleOfClimatePerceptions.pdf

Hoffman M, Lubell M, Hillis V (2014) Linking knowledge and action through mental models of sustainable agriculture. Proc Natl Acad Sci U S A 111(36):13016-13021. https://doi.org/10.1073/pnas.1400435111

Intergovernmental Panel on Climate Change. (2019). Special Report on Climate Change and Land. Retrieved December 4, 2020, from https://www.ipcc.ch/srccl/

Jabbour R, Zwickle S, Gallandt ER, McPhee KE, Wilson RS, Doohan D (2014) Mental models of organic weed management: comparison of New England US farmer and expert models. Renew Agricult Food Syst 29(4): 319-333. https://doi.org/10.1017/S1742170513000185

Jemison JMJ, Hall D, Welcomer S, Haskell J (2014) How to communicate with farmers about climate change: farmers' perceptions and adaptations to increasingly variable weather patterns in Maine (USA). J Agricult Food Syst Commun Develop 4(4):57-70. https://doi.org/10.5304/jafscd.2014.044.001 
Jew EKK, Whitfield S, Dougill AJ, Mkwambisi DD, Steward P (2020) Farming systems and conservation agriculture: technology, structures and agency in Malawi. Land Use Policy 95:104612. https://doi.org/10. 1016/j.landusepol.2020.104612

Jones C, Hine DW, Marks ADG (2017) The future is now: reducing psychological distance to increase public engagement with climate change. Risk Anal 37(2):331-341. https://doi.org/10.1111/risa.12601

Jones N, Ross H, Lynam T, Perez P, Leitch A (2011) Mental models: an interdisciplinary synthesis of theory and methods. Ecol Soc 16(1):160146. https://doi.org/10.5751/ES-03802-160146

Karmalkar AV, Bradley RS (2017) Consequences of global warming of $1.5^{\circ} \mathrm{C}$ and $2{ }^{\circ} \mathrm{C}$ for regional temperature and precipitation changes in the contiguous United States. PLoS One 12(1):e0168697. https://doi.org/10. 1371/journal.pone.0168697

Kingiri AN (2020) Agricultural advisory and extension service approaches and inclusion in reaching out to Kenyan rural farmers. Afr J Sci Technol Innov Dev 1(1):1-10. https://doi.org/10.1080/20421338.2020. 1823098

Knook J, Eory V, Brander M, Moran D (2020) The evaluation of a participatory extension programme focused on climate friendly farming. J Rural Stud 76:40-48. https://doi.org/10.1016/j.jrurstud.2020.03.010

Kosko B (1986) Fuzzy cognitive maps. Int J Man-Mach Stud 24:65-75

LaMere K, Mäntyniemi S, Vanhatalo J, Haapasaari P (2020) Making the most of mental models: advancing the methodology for mental model elicitation and documentation with expert stakeholders. Environ Model Softw 124:104589. https://doi.org/10.1016/j.envsoft.2019.104589

van der Linden S (2014) On the relationship between personal experience, affect and risk perception: the case of climate change. Eur J Soc Psychol 44(5):430-440. https://doi.org/10.1002/ejsp.2008

Maas A, Wardropper C, Roesch-McNally G, Abatzoglou J (2020) A (mis)alignment of farmer experience and perceptions of climate change in the U.S. inland Pacific Northwest. Clim Chang 162:1011-1029. https://oi. org/10.1007/s10584-020-02713-6

Marlon JR, van der Linden S, Howe PD, Leiserowitz A, Woo SHL, Broad K (2019) Detecting local environmental change: the role of experience in shaping risk judgments about global warming. J Risk Res 22(7): 936-950. https://doi.org/10.1080/13669877.2018.1430051

Meadow AM, Ferguson DB, Guido Z, Horangic A, Owen G, Wall T (2015) Moving toward the deliberate coproduction of climate sciencek. Weather, Climate, Soc 7(2):179-191. https://doi.org/10.1175/WCAS-D14-00050.1

National Agricultural Statistics Service (NASS). (2017). Census of agriculture. United States Department of Agriculture. https://www.nass.usda.gov/Publications/AgCensus/2017/index.php

Niles MT, Brown M, Dynes R (2016) Farmer's intended and actual adoption of climate change mitigation and adaptation strategies. Clim Chang 135(2):277-295. https://doi.org/10.1007/s10584-015-1558-0

Niles MT, Wiener S, Schattman RE, Roesch-McNally G, Reyes J (2019) Seeing is not always believing: crop loss and climate change perceptions among farm advisors. Environ Res Lett 14(4):044003. https://doi.org/ $10.1088 / 1748-9326 /$ aafbb6

Ohlmer B, Olson K, Brehmer B (1997) Understanding farmers' decision making processes and improving managerial assistance. Agric Econ 18:273-290

Oksanen J, Blanchet FG, Michael F, Roeland K, Pierre L, Dan M, et al. (2019) vegan: Community Ecology Package. R package version 2.54. https://cran.rproject.org/package=vegan

Olazabal M, Neumann MB, Foudi S, Chiabai A (2018) Transparency and reproducibility in participatory systems modelling: the case of fuzzy cognitive mapping. Syst Res Behav Sci 35(6):791-810

Özesmi U, Özesmi SL (2004) Ecological models based on people's knowledge: a multi-step fuzzy cognitive mapping approach. Ecol Model 176(1):43-64. https://doi.org/10.1016/j.ecolmodel.2003.10.027

Prokopy LS, Morton LW, Gordon J, Arbuckle J, Mase AS, Wilke AK (2015) Agricultural stakeholder views on climate change: implications for conducting research and outreach. Bull Am Meteorol Soc 96(2):1. https:// doi.org/10.1175/BAMS-D-13-00172.1

Prokopy LS, Carlton JS, Haigh T, Lemos MC, Mase AS, Widhalm M (2017) Useful to usable: developing usable climate science for agriculture. Clim Risk Manag 15:1-7. https://doi.org/10.1016/j.crm.2016.10.004

Schattman RE, Méndez VE, Merrill SC, Zia A (2018) Mixed methods approach to understanding farmer and agricultural advisor perceptions of climate change and adaptation in Vermont, United States. Agroecol Sustain Food Syst 42(2):121-148. https://doi.org/10.1080/21683565.2017.1357667

Schoell R, Binder CR (2009a) System perspectives of experts and farmers regarding the role of livelihood assets in risk perception: results from the structured mental model approach. Risk Anal 29(2):205-222. https://oi. org/10.1111/j.1539-6924.2008.01153.x

Schoell R, Binder C (2009b) Comparing system visions of farmers and experts. Futures 41(9):631-649. https:// doi.org/10.1016/j.futures.2009.04.006 
Takemura K, Uchida Y, Yoshikawa S (2014) Roles of extension officers to promote social capital in Japanese agricultural communities. PLoS One; San Francisco 9(3):e91975. https://doi.org/10.1371/journal.pone. 0091975

Tanaka K, Bhavsar VM (2008) The role of Southern SARE projects in enhancing the quality of life in rural communities in the South. S Rural Sociol Bowl Green 23(1):23-46

Taylor M, Bhasme S (2018) Model farmers, extension networks and the politics of agricultural knowledge transfer. J Rural Stud Elmsford 64:1. https://doi.org/10.1016/j.jrurstud.2018.09.015

Tobin D, Radhakrishna R, Chatrchyan A, Allred SB (2017) Addressing climate change impacts on agriculture and natural resources: barriers and priorities for land- grant universities in the northeastern United States. Weather, Climate, Soc 9(3):591-606. https://doi.org/10.1175/WCAS-D-16-0106.1

R Core Team (2019) R: a language and environment for statistical computing. R Foundation for statistical computing, Vienna URL https://www.R-project.org/

Ranjan P, Church SP, Floress K, Prokopy LS (2019) Synthesizing conservation motivations and barriers: what have we learned from qualitative studies of farmers' behaviors in the United States? Soc Nat Resour 32(11): 1171-1199. https://doi.org/10.1080/08941920.2019.1648710

Vallance S, Perkins HC, Dixon JE (2011) What is social sustainability? A clarification of concepts. Geoforum 42(3):342-348. https://doi.org/10.1016/j.geoforum.2011.01.002

Voinov A, Kolagani N, McCall MK, Glynn PD, Kragt ME, Ostermann FO, Pierce SA, Ramu P (2016) Modelling with stakeholders - next generation. Environ Model Softw 77:196-220. https://doi.org/10. 1016/j.envsoft.2015.11.016

Volpato G, King EG (2019) From cattle to camels: trajectories of livelihood adaptation and social-ecological resilience in a Kenyan pastoralist community. Reg Environ Chang 19(3):849-865. https://doi.org/10.1007/ s10113-018-1438-Z

White A, Faulkner J, Simis S, Tucker P, Weatherhogg K (2018) Report of the 2017-2018 New England Adaptation Survey for Vegetable and Fruit Growers. Department of Plant and Soil Science, University of Vermont, Burlington

Willock J, Deary IJ, McGregor MM, Sutherland A, Edwards-Jones G, Morgan O, Dent B, Grieve R, Gibson G, Austin E (1999) Farmers' attitudes, objectives, behaviors, and personality traits: the Edinburgh study of decision making on farms. J Vocat Behav 54(1):5-36. https://doi.org/10.1006/jvbe.1998.1642

Wolfe DW, DeGaetano AT, Peck GM, Carey M, Ziska LH, Lea-Cox J, Kemanian AR, Hoffmann MP, Hollinger DY (2018) Unique challenges and opportunities for Northeastern U.S. crop production in a changing climate. Clim Chang 146:231. Adapted by Glen Koehler. 2018. https://doi.org/10.1007/s10584-017-210

World Commission on Environment and Development (WCED). (1987). Our common future. Oxford: Oxford University Press

Publisher's note Springer Nature remains neutral with regard to jurisdictional claims in published maps and institutional affiliations.

\section{Affiliations}

\section{R. S. Clements ${ }^{1,2} \cdot$ S. K. Birthisel ${ }^{1,3} \cdot$ A. Daigneault ${ }^{3} \cdot$ E. Gallandt ${ }^{2} \cdot$ D. Johnson ${ }^{4} \cdot$ T. Wentworth $^{4}$ - M. T. Niles ${ }^{4}$}

1 Ecology and Environmental Sciences Program, University of Maine, Orono, ME, USA

2 School of Food and Agriculture, University of Maine, Orono, ME, USA

3 School of Forest Resources, University of Maine, Orono, ME, USA

4 Food Systems Program, College of Agriculture and Life Sciences, University of Vermont, Burlington, VT, USA 